\title{
Squamous cell carcinoma pada anjing rescue
}

\author{
Diah Pawitri ${ }^{1,2, *}$ \\ ${ }^{1}$ Praktek Dokter Hewan Bersama 24 jam drh. Cucu K.S, Sunter, Jakarta Utara, DKI Jakarta, INDONESIA \\ ${ }^{2}$ Vetnic veterinary clinic, Sumarecon Bekasi, Jawa Barat, INDONESIA
}

\begin{abstract}
ABSTRAK: Anjing rescue adalah anjing yang diadopsi atau mendapatkan rumah baru dari pemilik sebelumnya yang tidak mengurus, tidak memberi perhatian, melakukan kekerasan fisik dan atau membiarkan anjingnya berkeliaran di jalan. Squamous cell carcinoma merupakan tumor kulit yang banyak ditemukan pada hewan kecil khususnya terlalu banyak terpapar sinar matahari. Seekor anjing Pitttbull di rescue dan di bawa berobat ke klinik karena adanya massa cauliflower pada skapula kiri. Hasil pemeriksaan fisik dan berbagai pertimbangan pemilik, dilakukan operasi tanpa pemeriksaan penunjang laboratorium darah dan radiografi. Pengangkatan jaringan tumor dilakukan melalui tindakan bedah dimana daerah sayatan dibuat margin 2-3 cm pada jaringan sehat di sekitar tumor, penutupan area bedah dengan teknik teknik skin flapping. Pemeriksaan histopatologi jaringan tumor untuk penegakan diagnosa dan hasilnya diidentifikasi sebagai jenis cutaneous lokal ekstensif epidermal nekrosis dengan hiperkeratosis, parakeratotik dan othokeratotik dengan intradermal multifokus carcinoma (Squamous cell carcinoma non keratin) dan stromal fibroplasia.
\end{abstract}

Kata kunci:

anjing, rescue, squamous cell carcinoma

\section{- PENDAHULUAN}

Squamus cell carcinoma (SCC) merupakan tumor kulit terbanyak kedua pada anjing dan berasosiasi dengan aktinik keratosis, berkembang pada area peradangan kronis, perlukaan serta infeksi virus (Tilley \& Smith,1997). Aktinik keratosis dapat menginduksi SCC menjadi multipel tumor yang berasosiasi dengan lesio solar dermatitis (Wilkinson \& Richard, 1995). Squamus cell carcinoma merupakan tumor yang ulceratif dan proliferatif, serta mudah mengalami perdarahan (Withrow \& David, 2007). Tulisan ini melaporkan kasus squamus cell carcinoma pada anjing ras Pitbull jantan yang di-rescue yang ditangani dengan tindakan bedah.

\section{- KASUS}

Anamnesa dan sinyalemen: Seekor anjing Pitbull jantan di temukan di jalan 2 minggu sebelumnya dan di bawa ke klinik, dalam keadaan kurus. Pemeriksaan fisik: Terdapat massa pada dorsal tubuhnya di daerah skapula kiri berbentuk bulat diameter $6 \mathrm{~cm}$ (Gambar 1), kelihatan sakit pada kaki depan kiri saat berjalan. Hewan dalam kondisi kaheksia, dehidrasi, malnutrisi, rambut sangat tipis, kusam, hyperkeratosis, massa di atas skapula kiri berbau busuk, lesio sangat erosif dan ulceratif berbentuk cauliflower. Pemeriksaan penunjang: Karena satu dan lain hal pemilik tidak bersedia untuk dilakukan pemeriksaan penunjang foto radiografi dan pemeriksaan darah secara laboratorium. Pemeriksaan lanjut histopatologi dilakukan setelah tumor tumbuh kembali pascabedah. Diagnosa: Squamous cell carcinoma. Prognosa: Fausta. Terapi dan Penanganan:
Bedah untuk mengangkat massa tumor dan penutupan area bedah dengan teknik skin flapping.

\section{- HASIL}

Berdasarkan hasil pemeriksaan hewan didiagnosa malnutrisi dan tumor di atas skapula kiri. Tindakan bedah (operasi) pengangkatan massa tumor dilakukan setelah perbaikan kondisi tubuh selama 1 minggu. Operasi pengangkatan tumor dengan mengambil juga jaringan sehat $\pm 2 \mathrm{~cm}$ di sekelilingnya. Kondisi kulit sangat kering dan lengket. Otot serta jaringan subkutis sangat tipis tidak ada lapisan lemak.

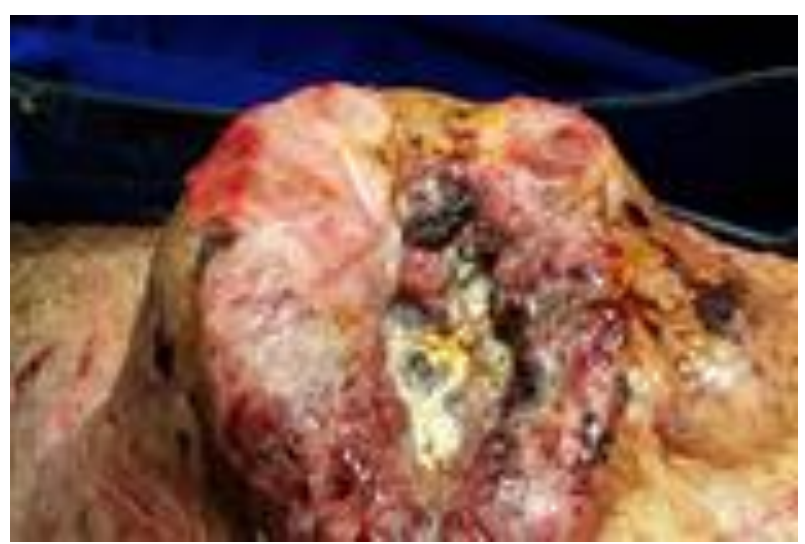

Gambar 1 Squamus cell carcinoma pada daerah skapula kiri.

Diterima: 14-03-2019 | Direvisi: 02-05-2019 | Disetujui: 10-05-2019 (C) 2019 CC-BY-SA. Ini adalah artikel Open Access yang didistribusikan berdasarkan ketentuan dari Creative Commons Attribution ShareAlike 4.0 International License (https://creativecommons.org/licenses/by-sa/4.0/). 
Empat bulan kemudian hewan datang kembali dengan keluhan tumbuh massa tumor yang berbentuk sama dengan massa tumor sebelumnya. Ukuran massa lebih kecil dengan diameter $\pm 2.5 \mathrm{~cm}$ di daerah anterior jahitan operasi pertama (Gambar 2A) dan di daerah ekor dengan diameter $\pm 2 \mathrm{~cm}$ (Gambar 2B). Bedah pengangkatan massa tumor kembali dilakukan dengan mengambil jaringan sehat lebih lebar \pm 3 $\mathrm{cm}$, dilakukan skin flap untuk menutup bagian yang terbuka dan caudektomi.

Perawatan dan pengobatan postoperasi pada hewan diberikan berupa antibiotika cefadroxil $22 \mathrm{mg} / \mathrm{kg}$ berat tubuh BID, vitamin B komplek dan piroxicam $0.3 \mathrm{mg} / \mathrm{kg}$ berat tubuh SID. Massa tumor yang terangkat kemudian dilakukan pemeriksaan histopatologi dan ditegakkan diagnosa morfologi sebagai cutaneous lokal ekstensif epidermal nekrosis dengan hiperkeratosis parakeratotik dan othokeratotik dengan intradermal multifokus carcinoma (squamous cell carcinoma non keratin) dengan stromal fibroplasia.

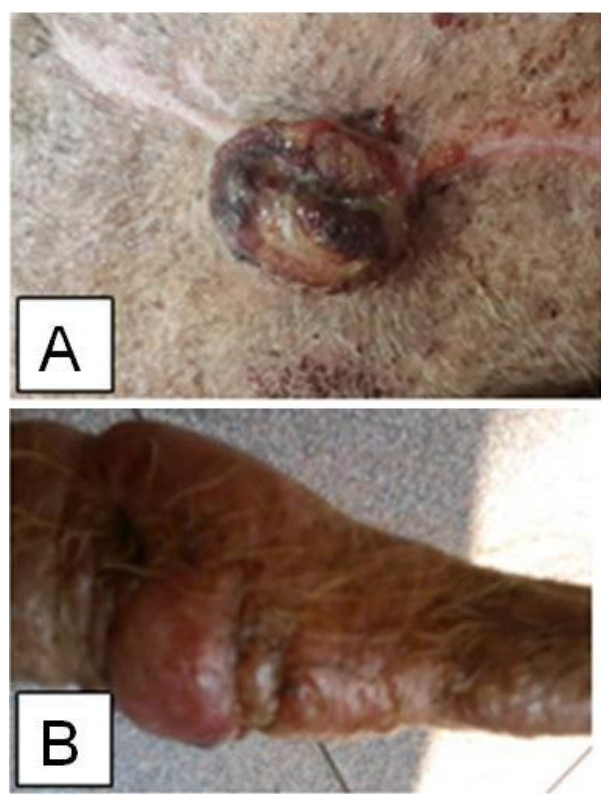

Gambar 2 Squamus cell carcinoma pada daerah sekitar persembuhan pasca bedah (A) dan daerah ekor (B)

\section{- PEMBAHASAN}

Berdasarkan pemeriksaan fisik terlihat hewan mengalami malnutrisi karena defisiensi protein dan kalori dalam waktu yang lama sehingga kulit menjadi kering, keratinisasi, bulu menjadi jarang dan kusam. Kehidupan hewan di jalanan mengakibatkan paparan sinar matahari pada tubuh terjadi secara berlebih dan menjadi predisposisi pertumbuhan tumor. Squamus cell carcinoma adalah malignant tumor yaitu suatu tumor yang invasif dan destruksi dapat berkaitan dengan infeksi virus papiloma atau paparan berlebihan sinar ultraviolet (Tilley \& Smith, 1997). Tumor ini sering tumbuh terutama pada kulit hewan yang tidak ada atau kurang memiliki pigmen melanin dan sedikit ditumbuhi rambut. Bentuk tumor yang tumbuh tampak seperti cauliflower, erosif dan ulceratif merupakan salah satu ciri khas dari squamus cell carcinoma (Wilkinson \& Richard, 1995). Squamus cell carcinoma adalah malignant tumor pada epitel squamosa umumnya di temukan pada kulit yang tidak ada atau sedikit pigmentasi. Patofisiologi tumor hingga saat ini masih belum diketahui dan umumnya berhubungan dengan paparan matahari, papilloma virus, dan abnormalitas molekular (Tilley \& Smith, 1997).

Operasi pengangkatan tumor merupakan tindakan yang dipilih pada kasus ini, sekaligus sebagai sarana pengambilan jaringan untuk penegakan diagnosa dan pengobatan selanjutnya. Pengangkatan tumor juga menyertakan jaringan sehat berukuran lebih dari $2 \mathrm{~cm}$ pada tiga dimensi, ditangani dengan hati-hati agar sel tumor tidak pecah atau robek dan luka dapat dibersihkan untuk meminimalisasi kemungkinan pertumbuhan kembali (Withrow \& David, 2007). Antibiotika yang dipilih adalah cefadroxil yang suseptibel pada kulit dan jaringan lunak, piroxicam sebagai analgesik, anti inflamasi, dan kemoterapi tumor (Allen et al., 1993). Mengacu pada World Health Organization yang memasukkan piroxicam dalam kelompok Nonsteroidal antiinflamatoryn Drugs pada golongan nonopioid analgesic (Withrow \& David, 2007). Evaluasi pada hewan dilakukan pada 4, 6, dan 12 bulan setelah tindakan dengan pemeriksaan fisik dan radiografi. Hewan tidak diperkenankan sering terpapar sinar matahari diantara pukul 10:00-14:00 waktu setempat sebagai tindakan preventif (Tilley \& Smith, 1997).

\section{- SIMPULAN}

Paparan sinar matahari yang berlebihan dapat menyebabkan tumbuhnya tumor kulit squamus cell carcinoma pada hewan yang mengalami malnutrisi berat, tubuh sedikit atau tidak memiliki melanin serta tidak ditumbuhi banyak rambut. Jaringan sehat $>2 \mathrm{~cm}$ disekitar tumor sebaiknya diambil saat operasi pengangkatan squamus cell carcinoma untuk mengurangi kemungkinan tumor dapat tumbuh kembali pada daerah yang sama.

\section{- INFORMASI PENULIS}

Penulis untuk Korespondensi

*DP: drh.diahpawitri@gmail.com

Vetnic veterinary clinic, Sumarecon Bekasi, Jawa Barat, INDONESIA

\section{- PUSTAKA ACUAN}

Allen DG, John KP, Dale AS, Peter C. 1993. Veterinary DrugHandbooks, Manual JB. Lippincott Company Philadelphia.

Tilley PT, Smith Jr FWK. 1997. Five Minutes Veterinary Consult Canine and Feline; William \& Wilkinsons Maryland,USA Pp1080-1081.

Wilkinson GT, Richard GH. 1995. Color Atlas of Small Animal Dermatology-A Guide to Diagnosis. Mosby-Wolfe Barcelona Spain. Chapter 11: 193-194; 14:227-228

Withrow SJ, David MV. 2007. Small Animal Clinical Oncology. Saunders Elsevier Inc.St Louis Misouri. Chapter 1: 19-21;10: 157-161;16:296-301;18: 375-379 